\title{
A Total Communication Package for the Business Executives: Importance of Attitude, Culture, Leadership and Other Factors
}

\author{
Nargis Akhter ${ }^{1}$, Sardana Islam Khan ${ }^{2}$, \& Nasrin Akter ${ }^{3}$ \\ ${ }^{1}$ Professor, Southeast Business School (SBS), Southeast University, Bangladesh \\ ${ }^{2}$ Lecturer, School of Business and Law, Central Queensland University, Melbourne, Australia \\ ${ }^{3}$ Assistant Manager - Human Resources, Merits Technologies Ltd, Bangladesh \\ Correspondence: Sardana Islam Khan, Lecturer, School of Business and Law, Central Queensland University, \\ Melbourne, Australia.
}

Received: September 14, 2020

Accepted: October 13, $2020 \quad$ Online Published: October 21, 2020

doi:10.5539/ibr.v13n11p1

URL: https://doi.org/10.5539/ibr.v13n11p1

\begin{abstract}
Recent studies suggest that a series of contextually appropriate and effective communication training package is demanded by the employers and HR practitioners in the job market. However, the ways to design an effective, comprehensive and sustainable communication development program for the business executives have rarely been explored in the extant literature. This paper introduces the concept of a total communication package (TCP) that can help design a better communication development program for the business executives. This qualitative research uses the interview findings from 20 top executives from the banking and telecommunication sectors in Bangladesh to unpack the concept of TCP for the HR practitioners.
\end{abstract}

Keywords: communication skills, attitude, business executives, leadership, culture, Bangladesh

\section{Introduction}

Communication skill is one of the most important soft skills for the business executives according to the extant human resource management (HRM) literature (Akhter, Khan, \& Hassan, 2009). However, the ways to design an effective communication training or development program for the business executives have rarely been explored. There is also a dearth of quality research on the nuances of communication skills in a developing country context where English is a second language but used as the primary mode of communication in business organizations. This paper introduces the concept of a total communication package (TCP) based on the findings from in-depth interviews with 20 business executives to unpack the complexity and unique demands on the communication training and development programs in Bangladesh.

This study is informed by two overarching research questions: (1) What communication related knowledge, skills, attitude, and other factors are considered important in the context of Bangladeshi business organizations and why? and, (2) How do these knowledge, skills, attitude, and other factors influence the communication outcomes of the business executives in Bangladesh?

\section{Literature Review}

\subsection{Significance of Communication Skills in Business Organizations}

Communication skills have been identified as one of the essential soft skills for business executives in the extant and seminal business and management literature (e.g., Katz1974; Kombarakaran et. al., 2008; Gerstein \& Keisman 1983; Bennett \& Olney 1986; Penley \& others 1991; Aiken, Martin \& Paolillo 1994; Clutterbuck \& Hirst 2002; Datar, Garvin \& Cullen 2011; Iksan et al. 2012; Akhter, Khan \& Hassan 2009; Paksoy, Soyer \& Çalik 2017; Smith 2017). Katz (1974) identified three basic skills for the business executives, i.e., technical, human, and conceptual skills, of which, human skill includes communication skill along with some other qualities. According to Penley and colleagues (1991), managerial performance essentially depends on communication skills. Based on a study on senior business executives, Aiken, Martin and Paolillo's (1994) study also marked communication as the most crucial skill for the business school graduates. Clutterbuck and Hirst (2002) identified communication as central to the four management competencies defined by Warren Bennis (management of attention, connotation, trust and self). 
Kombarakaran and colleagues (2008) surveyed 114 executives and 42 coaches and found that executive coaching for leadership development encompasses five areas and 'dialogues and communication' was identified as one of these five areas. Gerstein and Reisman (1983) contended that senior managers need proper communication with peers, subordinates and superiors. Bennett and Olney (1986) conducted a study on executives from Fortune 500 companies which reflected that effective communication is vital for business success in the information society and is exceedingly important for the higher-level executive jobs. The study calls for especial attention of the academicians in developing pragmatic curricula of business communication courses and suggested sequential offerings of three courses on written, spoken and interpersonal communication and emphasized on the responsibility of the academics to convey the necessity of excellent communication skills for the students' success in executive jobs in the information society. Similarly, Katz (1974) suggested that academics should ensure the requisite communication skills for the students of 1980s for their future professional roles. Based on twenty-five studies in the previous ten years, Salvo (1980) contended that teachers should be aware about the requirement for particular communication skills for students as they will need these communication skills when they enter the job market.

In line with the earlier business communication literature, Iksan et al. (2012) also emphasized on the role of universities in creating graduates to address the job market demands. According to the authors, the universities should equip graduates to contest in the global job market and satisfy the employers' countless demands of soft skills and personality. The researchers emphasized on the inclusion of communication skills in the higher education course contents, the lecturer's feedback on students' communication and participation in various activities to help advance their communication skills for the future work life. Although the research was conducted on verbal (including listening), writing and social communication skills, the authors also emphasized on non- verbal communication skills, the importance of which remains under investigated till date especially in the context where English is the second language but used as the primary mode of communication in the office. In academia and professional training context as well, the non-verbal communication skills and other facilitators for effective communication are visibly underrepresented.

Akhter, Khan and Hassan (2009) found that the executives have positive attitudes towards the importance of communication course intended for executives. Most of the executive respondents completed communication course and they were dissatisfied with it. The respondents recommended compulsory communication training program in business organizations and suggested that academics should design and teach communication courses based on the employers' perspectives and requirements. Similarly, Paksoy, Soyer and Çalik (2017) argued that communication is a vital executive skill and manager-employee communication is critical for effective management. According to Smith (2017), communication is fundamental to the progress of both employees and business organizations and ineffective communication leads to loss of profit. The author identified trust, technology, face-to-face communication and smooth implementation of change through inclusive meetings as four important factors to ensure effective communication especially in health care sector. They argued that appropriate strategies to increase communication during change may help improve employee morale and profitability.

Robels (2012) study shows that out of 10 identified soft skills, business executives perceive communication, integrity and courtesy as the most important interpersonal skills for achievement. The research identified both hard and soft communication skills as equally important. Another study by Datar, Garvin and Cullen (2011) recommended business schools to go over the information, constructions, and theories included in the course contents and readjust their curricula to include communication skills, competence, and techniques. Based on the responses from deans and executives, the same study identified critical thinking and clear communication as two most important aspects of the eight required competencies.

Extant business communication and HR literature also emphasized on the importance of communication skills in non-managerial roles and technical experts in an organization. For example, Chohren (2015) mentioned that although employers consistently mentioned communication as one of the most cherished soft skills in business organizations, these skills are regrettably overlooked in the engineering discipline. The author contended that technical experts or professionals also need superior communication skills to effectively share research progress or objectives, effectually backup their company's product or service to a buyer, or to facilitate the buyer and peer training, which brings benefits to both engineers and employers. 


\subsection{Types and Contents of Communication Skills}

Salvo (1980) revealed that the communication skills that were acknowledged for the most part were listening, written, oral, persuasive interpersonal skills, informational meetings and problem solving in small group. Cohn (2007) claimed effective listening to be a major requirement for effective communication. The researcher also argued that merely eight percent of communication is associated with topic, while the remaining relates to body language and tone of voice. Cohn (2007) also emphasized on the significance of considering communication as process, based on attitudes, knowledge, emotions, integrity from communicator's side and the receiver's diversity, emotions, attitudes, knowledge, integrity and so forth. Bambacas and Patrickson (2008) found that senior HR managers require the interpersonal skills such as precision and regularity of the message, the capacity to listen effectively and ability to lead in a collective way. Among these interpersonal skills, the methods of sending messages, particularly their precision and the leadership style that stimulated trust were given highest importance to boost the organizational commitment which was typically lacking.

Bambacas and Patrickson (2009) contended that even though communication skills such as interpersonal, speaking, listening and written skills are important for successful managerial performance, HR managers only evaluate these casually through managerial selections. The researchers suggested that HR staff must thoroughly examine their practices of the evaluation of communication skills of the candidates for managerial positions and provide training on communication skills after conducting effective training need assessment.

Majid et al., (2010) stated that the four crucial communication skills are reading, writing, listening and speaking. Hull (2012) emphasized that effective interpersonal communication does not refer to transmitting or attaining what was planned to achieve and rather requires the ability to construct and transmit proper replies, recognize and explicate creative, satisfactory answers, and inspire people to modification. It happens in functional verbal and nonverbal communications and through an environment which is favorable to fruitful communication. Bennett and Olney (1986) conducted a study by taking samples of executives from Fortune 500 companies. The common consent of the executives was that effective communication skills are vital for business success nowadays and will remain vital in future especially in an information society. The study revealed that communications skills are more important in the higher and peak positions in executive jobs.

Bennett and Olney (1986) emphasized on the impact of technological progress in the communication processes. The authors identified interpersonal, writing, and speaking as vital communication skills and lack of skills regarding precision, listening, brevity, speaking and analysis as the major communication problems. Gerstein and Keisman (1983) argued that senior managers need proper communication with peers, subordinates, superiors and others and the proper communication demands effective and efficient written material, formal presentation methods, verbal communication, listening, communication media, communication contents and so forth.

\subsection{Roles of Leadership, Trust, Culture and Attitude in Effective Communication}

Johnson and Bechler (1998) studied the link between listening efficacy and leadership emergence in the task-oriented small group. The study revealed that emergent leaders usually show more active listening skills than the other members. To be truly effective both leaders and managers must develop their self-awareness, become role model for communication in the organization and learn to encourage and manage constructive decent. An important part of the communication professional's role is to support the organization's leaders and managers in developing their communication competence. Luthra and Dahiya (2015) identified outstanding communication as an essential skill for an effective leader. Exceptional leaders know that a clear goal direction necessitates open, two-way communication and a trusting communication culture where one will treat another as friends and task partners. Extant literature suggested that functional communication demands two-way communications which may help to develop leadership and entrepreneurial skills among students (see Majid et al., 2010; Abbasi, Siddiqi, \& Azim, 2011). Whitener et al., (1998) mentioned that credibility is linked to three communication features, i.e., accurate information, explanations for decisions and openness. Communication culture is the gum that holds teams and organizations united and this gum can be a motorist or a hurdle to performance (Decker \& Mitchel, 2017).

\subsection{Communication Outcomes: The Strategic Significance of Communication}

Zerfass and Viertmann, (2017) argued that relating communication to business strategy is one of the key challenges for communication professionals. The 12 major values that can be attained through corporate communication can be allied to the four core corporate values. The researchers have recognized four major value propositions of communication which are facilitating operations, constructing intangibles, bending strategy, and confirming flexibility. 


\subsection{Role of Communication in Planning}

Berger (1997) proposed that since communication, plans, and planning are related, communication discipline should include strategic social interaction which can contribute in planning. MacDonald (1976) also identified planning, mapping communication networks, recognizing communication-based roles and observing the characteristics of role occupants as important factors influencing the process of communication and outcomes.

\subsection{Communication, Job Satisfaction, Employee Engagement and Citizenship Behaviour}

Paksoy, Soyer and Çalik (2017) found a positive, bi-directional and moderate relationship between managerial communication skills and job satisfaction and job commitment and positive, bi-directional but weak relationship between job satisfaction and job commitment. The researchers advocated for increasing the number and level of training to improve communication skills among managers. Dasgupta, Suar and Singh (2013) revealed that assertive style of communication imparts highest sustenance to employees and perceived supervisory support at the workplace enhances employees' satisfaction with communication of supervisors and self-esteem. Employees' satisfaction regarding communication nurtures a resilient emotional connection with organizations which in turn declines employees' absenteeism, increase employee performance and commitment. The researchers suggest training program to mend assertive communication style among managers.

Kang and Sung (2017) found that internal communication management and employee engagement are linked, and employee engagement increases cooperation and minimizes the turnover intent. The researchers suggested that the organizations should implement a two-way, employee-centered symmetrical communication method in its daily communication management. Graen and Scandura (1987) argued that a mutually supportive relationship between managers and employees help increase dependability, cooperation, belief and innovativeness in the team. Firth et al. (2004) mentioned that supervisors' emotional care and self-esteem reconciled the effect of stressors on stress reactions, organizational commitment, job satisfaction and employee turnover. The researchers also emphasized on the relationship between supervisors and subordinates to decrease and cope up with stress. The significance of trustworthy and open communication culture between leader and member and role modeling of open communication by the managers were also highlighted by Cullen and Gordon (2014). Their findings revealed that nurse managers with effective leadership and communication skills helped enhance the organizational citizenship behaviors of the nursing team.

\subsection{Language and Communication}

Revell (2007) mentioned in his study that since people from different language and cultural background communicate for business purpose especially in meeting due to globalization and internationalization of trade, they frequently use English as an international language. Therefore, a person whose first language is not English is a challenge for them. This study focused on the use of English for International Business (EIB) at a particular business organization and extracted language issues, probable communication difficulties and frustrations that may exist in international contexts. The study also focused on the consciousness among some respondents to take strategies to beat these issues. Moreover, the author emphasized on the appropriate use of medium or mediums of communication, proper organization of the contents, language, non-verbal cues time, and place of communication. He also argued that a functional meeting is that meeting which is not arranged only for reporting information rather it can reinforce the team goals and spawned solutions. He mentioned that conflict is unavoidable but effective communication can help in eluding conflict and can reduce the magnitude of adverse effects when it arises.

Majid et al., (2010) attempted to explore the significance of communication skills in teaching, the social aspect, knowledge progression, and the implication of interpersonal interaction that relates to the students' emotional growth. Abbasi, Siddiqi, and Azim (2011) also contended that English language skill is vital for academic achievement since it has become an international language. The authors identified reading, writing, listening and speaking in English as crucial communication skills for the business executives especially in the non-English-speaking countries. The students with these crucial communication skills in English language have a better chance to be successful in academic and professional career as well.

\subsection{Gender and Communication}

Sistrunk and McDavid (1971) emphasized on the importance of cultural expectation of compliance and submissiveness in the female role as an important driver of group behavior. However, Markel, Long, and Saine's (1976) findings show that both male and female communicators speak more during the conversation when the listener is female. The findings also show that the average speech duration per utterance is expressively lengthier in case of female communicator. This was especially true in case of newly graduated female executives back in 
mid 1970s which most likely implicates a transition in the male-female dynamics of communication dominance that may vary across cultural contexts.

\subsection{The Impact of Globalization and Change in Technology in Communication}

Groysberg and Slind (2012) argued that the effectiveness of managing by "command -and -control" and its complementary pattern of corporate communication has been abruptly lessened due to globalization and change in technology. The leaders can endorse the working flexibility, employee commitment and well fit strategic orientation by speaking with employees. Drussell (2012) found that although the respondents think that face-to-face communication is the most functional and desirable ways to communicate and the most functional and chosen means of communication and conflict resolution, they take part in daily social networking activities at a higher rate than face to face communication and they use face book and text message for communicating and conflict resolution. The researcher recommended further study to observe whether social networking is related to communication skills and resolution of conflict and whether it impacts interpersonal working. Walther and Valkenburg (2017) analyzed historical dispute about the necessity for integration in theorizing about communication processes. Besides, it argues for the possibility of communication technologies to associate mass and interpersonal communication in ways that avoid the old-style distinction between both types, and how collaborative communication technology provides unparalleled analytic methods for research.

\subsection{Challenges in Developing Communication Capabilities among the Business Executives}

Cameron and others (2013) studied the procedure by which junior researchers acquire scientific communication skills from their mentors, their feelings about the challenges, and the part of their mentors in the procedure. The findings show that trainees' development of scientific communication skills is taxing and a difficult process both for trainees and mentors. They found that perceptions varied considerably about who is responsible for ensuring that trainees develop scientific communication skills. Trainees recognize that their mentors require these skills. However, they sensed that their mentors did not persistently support them in cultivating these skills and some mentors even failed to provide social and emotional care during the practice. Even though some trainees were happy with their scientific communication skills, many expressed low levels of confidence. Mentors stated that their trainees were not adequately cognizant of the prominence of scientific communication skills, sometimes showed negative attitudes or were disinclined to pursue resources and displayed poor communication skills. Bambacas and Patrickson (2009) suggested that HR staff must thoroughly examine their candidates' communication skills especially for the managerial positions and provide appropriate training based on proper training need assessment (TNA).

\section{Research Gap}

Our analysis of business communication literature reveals that both soft and hard communication skills are central to the business executives' performance and the quality of university curricula plays an important role in developing those skills. However, many other factors such as leadership or mentorship, organizational culture and environment, and trust are some of the relatively under explored factors and actors especially in some developing country contexts where English is the second language but used as the primary mode of business communication. In such contexts, the hard communication skills such as speaking, writing, listening and reading in English language are likely to be more emphasized by the educators, trainers and business executives whereas some other important communication contents such as non-verbal communication, cultural intelligence and attitude are overlooked in the training and development programs. So, based on the review of extant communication literature, we have identified a wide range of communication skills required for the business executives as well as some other important factors that may influence the effectiveness of the communication process in a business organization (see Figure 1). We, therefore, argue that a comprehensive framework for the development of communication capabilities in business organization, especially in such contexts is required to achieve a broad range of sustainable communication outcomes and our study aims at proposing such a total communication package (TCP) for Bangladeshi business executives, HR managers, educators and trainers. The findings will be useful for the similar developing countries. 


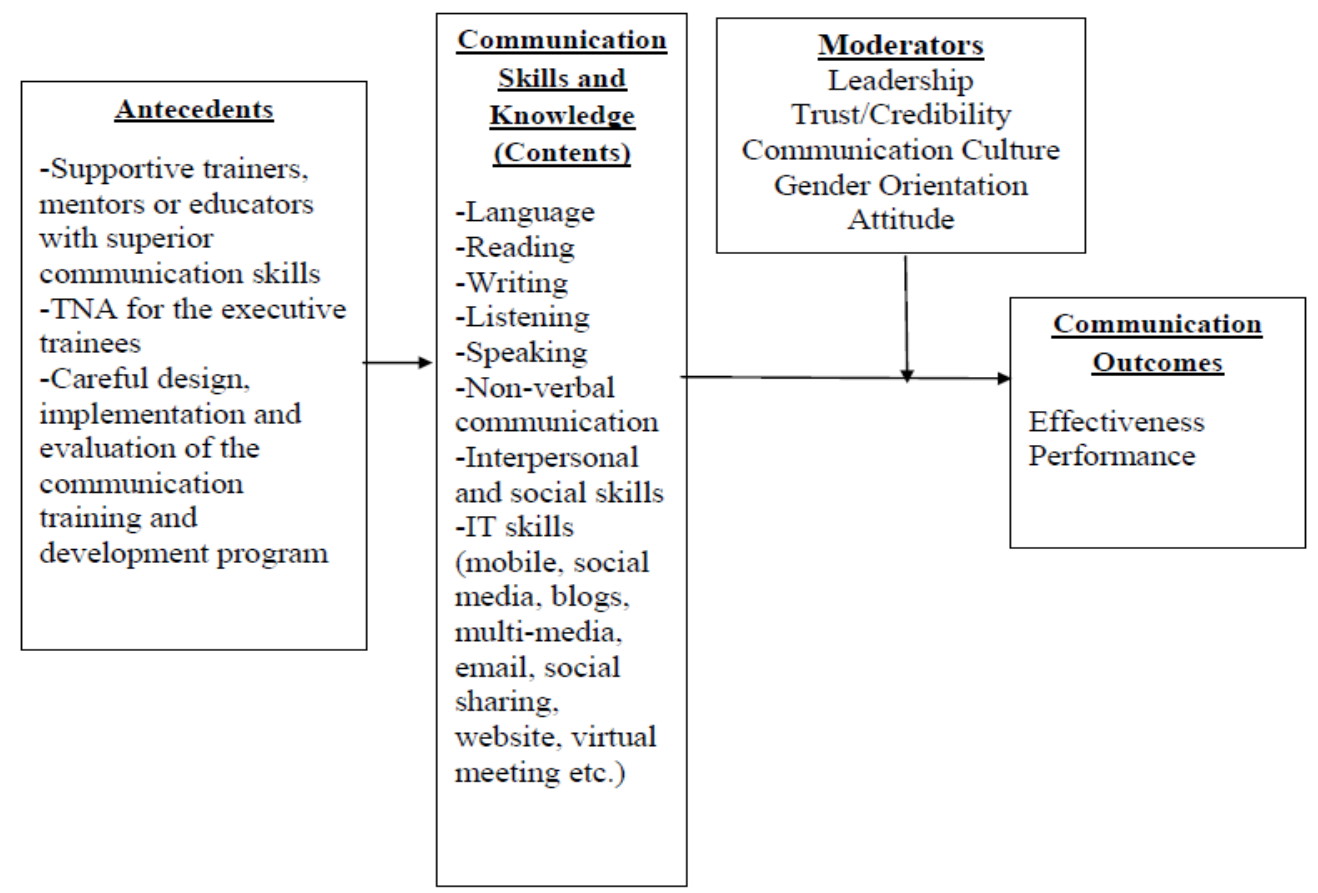

Figure 1. A Total Communication Package (TCP) for the Business Executives

\section{Methodology}

This qualitative research uses the data collected from 20 top executives from the banking and telecommunication sector in Bangladesh (see Table 1) to unpack the concept of TCP and recommends a sustainable communication capacity development framework for the HR practitioners. The respondents have more than 5 years of experience in the top-level executive positions with 2 or more employees currently working under their direct supervision, in a bank or telecommunication organization in Bangladesh. All selected respondents also hold at least a Masters level tertiary degree. The semi-structured interview agenda was designed around the communication knowledge, skills, attitudes and other factors. The voice recordings of these face to face interviews have been transcribed and then thematic approach has been used to analyze the data and identify the key themes. Two researchers have independently analyzed the data and corroborate the themes to ensure reliability.

Table 1. Respondents' Profile

\begin{tabular}{|c|l|l|c|c|c|c|}
\hline $\begin{array}{c}\text { Respondent } \\
\text { (Label) }\end{array}$ & \multicolumn{1}{|c|}{ Industry } & $\begin{array}{c}\text { Designation } \\
\text { and } \\
\text { Department }\end{array}$ & Gender & $\begin{array}{c}\text { Total Job } \\
\text { Experience } \\
\text { (years) }\end{array}$ & $\begin{array}{c}\text { Number of } \\
\text { Employees } \\
\text { Under Direct } \\
\text { Supervision }\end{array}$ & $\begin{array}{c}\text { Highest } \\
\text { Education/Academic } \\
\text { Degree }\end{array}$ \\
\hline 1 & $\begin{array}{l}\text { Banking and } \\
\text { Financial }\end{array}$ & $\begin{array}{l}\text { Senior Vice } \\
\text { President, } \\
\text { Human } \\
\text { Resources } \\
\text { Management }\end{array}$ & Male & 20 Years & 17 & $\begin{array}{c}\text { EMBA } \\
\text { Dhaka University }\end{array}$ \\
\hline 2 & $\begin{array}{l}\text { Banking and } \\
\text { Financial }\end{array}$ & $\begin{array}{l}\text { First Executive } \\
\text { Officer, } \\
\text { Clearing and } \\
\text { Accounts }\end{array}$ & Female & 10 Years & 03 & MBA \\
\hline 3 & Banking & $\begin{array}{l}\text { Vice President, } \\
\text { Head, Consumer } \\
\& \text { sale }\end{array}$ & Male & 23 Years & 27 & MBA \& FCMA \\
\hline 4 & Banking & Branch Manager & Male & 13 years & 17 & $\begin{array}{l}\text { MBA, IBA, Dhaka } \\
\text { University }\end{array}$ \\
\hline 5 & Banking & $\begin{array}{l}\text { Deputy } \\
\text { Manager, H/O }\end{array}$ & Male & 08 Years & 2 & $\begin{array}{l}\text { MBA (Finance),IBA, } \\
\text { Dhaka University }\end{array}$ \\
\hline
\end{tabular}




\begin{tabular}{|c|c|c|c|c|c|c|}
\hline 6 & $\begin{array}{l}\text { Non-Banking } \\
\text { Financial Institute }\end{array}$ & $\begin{array}{l}\text { Assistant } \\
\text { Manager, } \\
\text { Human } \\
\text { Resources }\end{array}$ & Male & 06 Years & 2 & $\begin{array}{l}\text { MBA, Dhaka } \\
\text { University }\end{array}$ \\
\hline 7 & Banking & $\begin{array}{l}\text { Head of Branch } \\
\text { Audit, ICCD }\end{array}$ & Male & 18 Years & 12 & MBA (Marketing) \\
\hline 8 & Banking & $\begin{array}{l}\text { Senior Assistant } \\
\text { Vice President, } \\
\text { Consumer CRM }\end{array}$ & Male & 15 Years & 8 & $\begin{array}{l}\text { MBA (Banking \& } \\
\text { Insurance) }\end{array}$ \\
\hline 9 & Banking & $\begin{array}{l}\text { Branch } \\
\text { Manager, FAVP }\end{array}$ & Male & 14 Years & 25 & $\begin{array}{l}\text { MSS, Dhaka } \\
\text { University }\end{array}$ \\
\hline 10 & Banking & $\begin{array}{l}\text { First Assistant } \\
\text { Vice President, } \\
\text { Foreign Trade }\end{array}$ & Male & 21 Years & 9 & $\begin{array}{l}\text { MBA (Finance \& } \\
\text { Banking), } \\
\text { IIUC }\end{array}$ \\
\hline 11 & Banking & $\begin{array}{l}\text { VP \& Manager, } \\
\text { Operations }\end{array}$ & Male & 17 Years & 35 & ACBA, IBA \\
\hline 12 & Banking & $\begin{array}{l}\text { Officer, Credit } \\
\text { Risk Mgt }\end{array}$ & Female & 7 Years & 10 & 10CMA (ICMAB) \\
\hline 13 & Banking & $\begin{array}{l}\text { First } \\
\text { Assistant Vice } \\
\text { President, } \\
\text { Shariah Council } \\
\text { Secretariat }\end{array}$ & Male & 22 Years & 8 & $\begin{array}{l}\text { MPhil, Aligarh } \\
\text { Muslim University, } \\
\text { Agra }\end{array}$ \\
\hline 14 & Banking & $\begin{array}{l}\text { Branch } \\
\text { Operation } \\
\text { Manager, } \\
\text { Distribution } \\
\text { Network } \\
\end{array}$ & Male & $11+$ Years & 35 & $\begin{array}{l}\text { MBA (Finance \& } \\
\text { Banking), IIUC }\end{array}$ \\
\hline 15 & Telecommunication & $\begin{array}{l}\text { General } \\
\text { Manager, } \\
\text { Process } \\
\text { Excellence }\end{array}$ & Male & $14+$ Years & 02 & $\begin{array}{l}\text { MBA, North South } \\
\text { University }\end{array}$ \\
\hline 16 & Telecommunication & $\begin{array}{l}\text { Manager, } \\
\text { Insight \& } \\
\text { Customer } \\
\text { Experience }\end{array}$ & Male & 15 years & 2 & MBA \\
\hline 17 & Telecommunication & $\begin{array}{l}\text { General } \\
\text { Manager, } \\
\text { Human } \\
\text { Resources }\end{array}$ & Male & 15 Years & 8 & $\begin{array}{l}\text { MBA, North South } \\
\text { University }\end{array}$ \\
\hline 18 & Telecommunication & Lead Specialist & Male & 15 Years & 10 & $\begin{array}{l}\text { MBA, North South } \\
\text { University }\end{array}$ \\
\hline 19 & Telecommunication & $\begin{array}{l}\text { Senior } \\
\text { Specialist } \\
\end{array}$ & Male & 17 Years & 7 & $\begin{array}{l}\text { MBA, North South } \\
\text { University }\end{array}$ \\
\hline 20 & Telecommunication & $\begin{array}{l}\text { Head of Supply } \\
\text { Chain } \\
\text { Management }\end{array}$ & Male & 22 Years & 38 & FCMA \\
\hline
\end{tabular}

\section{Findings and Analysis}

The findings of the study have been presented in four major sections around three major 'a priori' and 'posteriori' themes: (1) communication knowledge, skills and attitude (KSA); (2) other factors influencing the communication contents and process, and (3) communication outcomes. Some of the key agenda, probing questions, and major findings and themes from the responses have been presented in Table 2 . 
Table 2. Interview Agenda and Key Themes Emerging from the Findings

\begin{tabular}{|c|c|c|}
\hline Key themes & Probing questions & Themes emerging from the response \\
\hline Language & $\begin{array}{l}\text { 1. Does your organization give the highest } \\
\text { importance on English language proficiency when } \\
\text { the organization checks communication skills of } \\
\text { candidates for executive jobs and take decisions } \\
\text { regarding the promotion of executives? }\end{array}$ & $\begin{array}{l}\text { Includes both affirmative and negative responses } \\
\text { with more organisations acknowledging the } \\
\text { English language skill as one of the most } \\
\text { essential communication skills. }\end{array}$ \\
\hline Knowledge & $\begin{array}{l}\text { 2. Do you think knowledge of the communication } \\
\text { process and intended outcome is important in } \\
\text { developing the communication capacity in an } \\
\text { organization? Explain } \\
3 \text {. How do you think this knowledge of } \\
\text { communication process and outcome can be } \\
\text { developed or improved? } \\
4 \text { Do current education programs ensure these } \\
\text { knowledge outcomes? Why or why not? }\end{array}$ & $\begin{array}{l}\text {-Most respondents believed a comprehensive } \\
\text { knowledge of the communication process is } \\
\text { important. } \\
\text {-Effective Business Communication Course at } \\
\text { Undergraduate and Graduate Levels (One for } \\
\text { each). } \\
\text {-Three (03) courses should be covered on } \\
\text { business communication which are written, } \\
\text { spoken and nonverbal. } \\
\text {-Current education programs do not always } \\
\text { ensure the knowledge outcomes required by the } \\
\text { organizations. } \\
\text {-Besides Business Communication Courses, } \\
\text { faculty members initiatives to improve } \\
\text { communication knowledge of the students in } \\
\text { other courses is imperative. }\end{array}$ \\
\hline \multirow[t]{3}{*}{ Skill } & $\begin{array}{l}\text { 5. What communication skills are important in your } \\
\text { day to day operations? }\end{array}$ & $\begin{array}{l}\text { Speaking, Listening, Reading, Writing, } \\
\text { Non-verbal Communication (eye contact, facial } \\
\text { expressions, gestures, posture, body orientation, } \\
\text { body language, space and distance, proximity, } \\
\text { para-linguistic, etc.) }\end{array}$ \\
\hline & 6. How can these skills be best developed? & $\begin{array}{l}\text {-Speaking, viva-voce, teamwork, role play, } \\
\text { debate, report writing and presentation } \\
\text {-Using different modes of assessment such as in } \\
\text { others courses public speaking, viva-voce, } \\
\text { teamwork, role play, debate, report writing and } \\
\text { presentation in other courses } \\
\text { - Communication Skills Training } \\
\text { - Mentoring by direct supervisor } \\
\text { - Team work } \\
\text { - Role Modeling by direct supervisor } \\
\text { - Role Modeling by CEO } \\
\text { - Incentives for Best Communicators }\end{array}$ \\
\hline & $\begin{array}{l}\text { 7. Do current programs ensure these outcomes? Why } \\
\text { or why not? }\end{array}$ & $\begin{array}{l}\text { Responses are predominantly negative. The } \\
\text { major reasons included lack of knowledge and } \\
\text { informed pro-active TNA and training } \\
\text { evaluation }\end{array}$ \\
\hline \multirow[t]{2}{*}{ Attitude } & $\begin{array}{l}\text { 8. What kind of attitude is important for effective } \\
\text { communication in an organization? }\end{array}$ & $\begin{array}{l}\text {-Communication Skill is the most important } \\
\text { skills for executives for doing job effectively } \\
\text { and efficiently. } \\
\text {-We should take appropriate measures to } \\
\text { develop excellent communication skills of ours } \\
\text { and our executives. } \\
\text { Communication Skills of employees have } \\
\text { strategic significance. }\end{array}$ \\
\hline & $\begin{array}{l}\text { 9. What kind of attitude is important for a participant } \\
\text { in communication training and development } \\
\text { programs? } \\
\text { 10. Do current development programs ensure these } \\
\text { outcomes? Why or why not? }\end{array}$ & $\begin{array}{l}\text {-Communication Skill is the most important } \\
\text { skills for executives for doing job effectively } \\
\text { and efficiently } \\
\text { - Since training provides an opportunity to learn, } \\
\text { if we try to learn sincerely from training on } \\
\text { communication, we will be able to develop } \\
\text { knowledge and skills regarding communication. } \\
\text {-Current programs do not focus on attitude }\end{array}$ \\
\hline $\begin{array}{l}\text { Organizational } \\
\text { Culture }\end{array}$ & $\begin{array}{l}\text { 11. Do you think organizational culture is important } \\
\text { in effective communication? } \\
\text { 12. What type of culture is congenial to ensure } \\
\text { effective communication in an organization? }\end{array}$ & $\begin{array}{l}\text {-All participants responded affirmatively. } \\
\text {-Trust among organization members regarding } \\
\text { each other otherwise information will be } \\
\text { distorted during communication } \\
\text {-Incentives for executives for excellent }\end{array}$ \\
\hline
\end{tabular}




\begin{tabular}{|c|c|c|}
\hline & & $\begin{array}{l}\text { knowledge, skills \& attitudes (KSAs) towards } \\
\text { communication } \\
\text {-Executives' confidence regarding employers' } \\
\text { commitment to provide incentives for excellent } \\
\text { knowledge, skills \& attitudes (KSAs) towards } \\
\text { communication } \\
\text {-Role Modeling by direct supervisor } \\
\text { Mentoring by direct supervisor } \\
\text {-Role Modeling by CEO } \\
\text {-Allocating required budget for communication } \\
\text { training } \\
\text {-Required Leave for Educational Program to } \\
\text { improve communication skills. }\end{array}$ \\
\hline & $\begin{array}{l}\text { 13. Do you think leaders in organizations can } \\
\text { facilitate or enhance the outcomes of communication } \\
\text { training or development programs? If yes, how? }\end{array}$ & $\begin{array}{l}\text {-Allocating required budget for communication } \\
\text { Skills Training } \\
\text {-Ensuring effective training process on } \\
\text { communication skills } \\
\text { Required leave for education to improve } \\
\text { communication skills } \\
\text {-Ensuring required return on investment (ROI) } \\
\text { from Communication Training } \\
\text {-Role Modeling by direct supervisor regarding } \\
\text { communication skills } \\
\text {-Mentoring by direct supervisor regarding } \\
\text { communication skills } \\
\text {-Role Modeling by leader regarding } \\
\text { communication skills Incentives for executives } \\
\text { for excellent knowledge, skills and attitudes } \\
\text { (KSAs) towards communication. } \\
\text {-Executives' confidence regarding employers' } \\
\text { commitment to provide incentives for excellent } \\
\text { knowledge, skills \& attitudes (KSAs) towards } \\
\text { communication } \\
\text {-Trust among organization members regarding } \\
\text { each other; otherwise information will be } \\
\text { distorted during communication } \\
\text {-Continual Evaluation of executives' } \\
\text { communication skills \& take further decision on } \\
\text { the basis of it. }\end{array}$ \\
\hline Other factors & $\begin{array}{l}\text { 14. What other internal or external factors and actors } \\
\text { are important to ensure and sustain the outcomes of } \\
\text { communication trainings and capacity building } \\
\text { programs? } \\
\text { 15.Do you think emotional and cultural intelligence } \\
\text { is important for effective communication? Explain. }\end{array}$ & $\begin{array}{l}\text { Many other factors such as emotional and } \\
\text { cultural intelligence have been identified. }\end{array}$ \\
\hline $\begin{array}{l}\text { Communication } \\
\text { outcomes }\end{array}$ & $\begin{array}{l}\text { 16. How do you measure the outcomes of effective } \\
\text { communication? } \\
\text { 17. How do you measure the outcome of a } \\
\text { communication skill development program? } \\
\text { 18. What other factors (apart from the merit of the } \\
\text { training or development programs) may contribute in } \\
\text { achieving those outcomes? } \\
\text { 19. Do you think that executives' communication } \\
\text { skills have influence on organizations' strategic } \\
\text { achievements? How? }\end{array}$ & $\begin{array}{l}\text { The respondents generally expressed } \\
\text { dissatisfaction about the evaluation process and } \\
\text { criteria of evaluation. Many other factors such } \\
\text { as competence of the trainer has been identified } \\
\text { as the deterrent. The findings predominantly } \\
\text { show that communication skills of the } \\
\text { executives often directly contribute to the } \\
\text { achievement of organisational outcomes and } \\
\text { development process (OD). }\end{array}$ \\
\hline
\end{tabular}

\subsection{Communication KSA}

All respondents agreed that the knowledge of the communication process and intended outcomes are as important as the skills in developing the communication capacity in an organization which is currently lacking. They identified the knowledge about the effective communication process and intended outcomes vital for the continuous and future improvement of communication skills and capacity building. For example, respondent 1 stated,

"Without knowledge it is not possible to develop skills and both personnel and organization will suffer in the completive market to survive and to get result from their performance as well as to achieve their goals". 
Similarly, respondent 8 stated,

"Firstly, knowledge is a vital matter to develop skills. Without proper knowledge there is no chance to get expected performance from them. If knowledge is not appropriate there is chance of misguidance to get result from the performance of the employees".

Respondent 10 emphasized on the link between the knowledge of the communication process and outcomes and the organizational performance in the following statement,

"As human are social beings, in every step of our life we need communication skill to build up public relationship which is mostly important in the business sector to provide excellent customer service. If there is a gap between knowledge of communication and the value of outcomes, the right information cannot be expressed properly to the customers, the stakeholders and the clients. Knowledge of such sort would educate the employees to further enhance their required communications skills".

The respondents also acknowledged the importance of communication skill as "the major criteria for career development especially in the service industries. It is very important for an employee to be a good communicator in every aspect. Without the capacity of communication, an employee cannot be succeeded in his or her career at all" (R-2). Many respondents identified the importance of communication capacity as crucial "for multinational companies which have multidimensional people from different countries" (R4).

\subsubsection{Role of Academia}

In response to the question about whether the current education programs ensure the required communication knowledge in Bangladesh only 7 out of 20 respondents answered affirmatively, while majority (12 respondents) said that the current academic curricula fail to effectively address the job market's demand for communication knowledge and capability and one respondent was uncertain about the condition. Those who responded affirmatively mainly expressed their satisfaction with the communication capabilities of a few leading universities in Bangladesh for including different types of creative writing and speaking through different courses both at the undergraduate and post-graduate level which help student to enrich their knowledge. For example, R 18 said,

"Communication process, attitude and behavior of the interns and new employees can be measured through their performance and represent the outcomes of their knowledge. Therefore, it can be said that current education programs ensure these knowledge outcomes. They are getting opportunity to achieve knowledge through these education processes especially in some specific universities such as Dhaka University, North South University, BRAC University and East West University".

Many respondents mentioned that the students in Bangladesh focus more on securing a better grade rather than developing their communication capabilities or building knowledge. R-15 stated, "the students are CGPA oriented; they only focus on how to get more CGPA without learning and acquiring knowledge now a days. The presence of participatory approach is at highly dissatisfactory level". Others suggested that communication skills should be the focus of the school curricula as well to gradually build up the communication capabilities. Some of the respondents emphasized on developing English language skills. For example, R-13 stated,

"I do not know about the education process, but BBA \& MBA Programs cover communication courses so that the students get the basic knowledge of communication skills. But actually, communication skills must be developed from childhood. Except English medium schools, most of Bangla medium schools do not cover the course regarding communication skills. Communication skill development related courses should be included from schools".

Other respondents highlighted the importance of extracurricular activities as an important way to develop communication skills and capabilities. R-16 said, "so, we have to focus on or enhance involvement and engagement by giving opportunity to the students by participating debate, club activities and like besides the regular studies".

Many respondents appreciated the syllabus and curricula but criticized the teaching method and evaluation process which in their opinion, do not ensure the outcomes of the knowledge. They expressed that there is a gap between the education programs and environment of the institutes. Some respondents suggested that there is a need to develop the structure of evaluation process and teaching method in the current education system. More practical knowledge and industrial practices should be added with the education and teaching method through presentation, case studies, industry visits, training session, seminars and job fair to enhance the students' practical knowledge as opposed to only theoretical contents to enhance their communication outcomes which will also help shape their future career path according to the respondents. For example, R7 stated, "there is a gap 
between education programs and industrial sector. They should ensure the involvement of the industry person to develop their education programs as well as curricula and syllabus based on practical work experience".

Similarly, R-10 said, "current education programs are not enough. The class session also should be taken by the educational expert in every semester to give a clear concept about the practical knowledge about the industry". R-8 emphasized on the use of state-of-the-art educational instruments and digital platform in the classroom which will help teach students the effective use of digital technology to enhance their communication capabilities for the future career growth. The respondent also believes that the teacher or the trainers are not well equipped or trained up for such kind of education.

\subsubsection{Role of Organizations}

In response to the question about the current system or opportunities provided by the organization to the business executives, 14 respondents answered affirmatively while the rest stated that no well-planned or focused development programs are in place in their organizations. Those who responded positively stated that they are getting the opportunity to develop communication skills and build up relationship by creating network and connectivity and creating business connectivity increases opportunity for further career growth as well which is a desirable outcome from the enhanced capability. R-10 stated that his organization has its own communication policy and code of conduct for communication. They also receive mentoring by the supervisor which helps them find out the knowledge and skills gap and through training they can address those gaps. Some other respondents mentioned that they have a post training evaluation process in place and trainees must present their training modules to other employees to share knowledge.

R-14 stated that "business executives often present their ideas in front of large audiences which ultimately develop their communication skills. Management also organizes different kind of communication courses and training to improve employees' presentation and public speaking skills through teamwork, role modeling and training courses".

\subsubsection{Knowledge and Proficiency in Using Digital Platform}

Many respondents identified the effective use of digital platforms as one of the most important communication skills in the current job market. R-11 stated that the communication process in his organization involves extensive use of digital platforms such as LinkedIn, Zoom, Microsoft team or WhatsApp for internal and external communication. Data management skills also help enhance the communication outcomes in according to some respondents.

\subsubsection{Importance of Attitude in Effective Communication}

Many respondents mentioned that both the managers and employees should sincerely acknowledge the importance of developing communication capabilities to ensure individual and organizational performance. Such awareness will help the managers for better designing and evaluating the communication training and development programs based on proper TNA. The business executives attending those trainings will also need to have a positive attitude towards these training or development programs and the importance of improving their communication knowledge and skills. Some respondents highlighted the positive learning spirits and cultural adaptability as two vital aspects of the positive communication attitude in the workplace and they associated prior academic institutional affiliation to such attitudes. For example, R-16 said, "our employees have adaptability to adjust to their organization's culture. As per my observation, employees who had come from mostly Dhaka University, North South University, American International University-Bangladesh, Independent University, Bangladesh, BRAC and East West University have positive attitudes to adapt and support the responsibilities of their job to handle it smartly". Apart from Dhaka University (only public university mentioned), most of the other universities mentioned by the respondents are among the top five private universities in Bangladesh. Some respondents have also emphasized on the importance of emotional and cultural intelligence of the business executives in ensuring the desired outcomes from superior communication knowledge and skills.

The respondents have explained how a positive attitude may the continuous and effective development of the communication soft skills of business executives. The executives with the right learning attitude and self-awareness are able to assess their own communication skill gap and compare their own skill with other. They can identify and follow an appropriate role model among their colleagues or superiors and easily align or adapt to the organization's culture. Such employees can also find free training and courses which are online based and easily accessible on their own and based on their own initiative and TNA. R-13 mentioned that an executive with cultural intelligence can learn by himself to cope up with multinational culture, have better 
adaptability to cope up with the changing system and work better in a team. "There are lots of learning opportunities other than formal training conducted by organization and an employee with the right learning attitude usually grabs those opportunities to improve their skills" (R-9). The respondents also emphasized on the usefulness of emotional intelligence in breaking ice and understanding and demonstrating the appropriate emotion in the work environment which in turn may help create a trusted relationship and a positive communication culture in the organization.

\subsection{Other Factors Influencing the Communication Contents and Process}

Many respondents attributed the environment or culture and work system in their organization as important contributors to the effective communication outcomes. R-16 stated that their organization created and facilitated an effective communication culture, "through learning and development programs, training, brain storming, job rotation, presentations in meetings, public speaking and town hall presentation so forth". They also provide other opportunities such as internal and external training on communication, teamwork and mentoring. Many respondents emphasized on maintaining an open, supportive and trusted environment in the organization to facilitate continuous evaluation and improvement of communication capabilities.

\subsubsection{Role of HR Department}

The HR Managers informed the researchers about their role and initiative to improve employees' communication KSA. R-15 said, "every year our organization allocates budget for developing communication KSA of employees which is 20 percent of the total budget". The organization provides training and other financial support to develop required skills for doing the job properly after doing Training Need Assessment. Renowned Trainers from organizations such as British Council or BDjobs.com are invited to provide these trainings. Another HR manager R-3 stated that "we got suggestion from the trainer that there should be a strategic unit for communication skill development- meaning an individual department which may have separate identity to ensure greater impact". Some HR managers stated that their department develops awareness about importance of effective communication among the business executives through the orientation programs to develop the right attitude from the get-go.

\subsubsection{Role of Leadership}

The respondents invariably emphasized on the importance of a leader's role in mentorship, role modeling and creating the right attitude about the content and process of communication among the employees. According to the respondents a good leader must build up trusted relationship with the peers and a supportive organizational culture to develop and sustain the communication KSA in their organization. They must allow sufficient budget allocation for employee development programs and arrange for regular presentation and public speaking opportunities which will help employees to continuously improve their communication skills and apply the learning from their trainings. Leaders and HR department should systematically evaluate executives and offer proper incentives to the best performer who have good communication skills and positive learning attitudes.

The leaders should also offer active mentorship to the business executives by being a role model, observing the regular activities of the executives and providing timely and appropriate feedback to improve their communication skills and outcomes. They should also create awareness among the employees about the importance of improving their communication skills to survive in the competitive market. The leaders and HR must also collect and use the feedback from the executives about the communication training and development programs and how to improve these programs.

\subsection{Communication Outcomes}

Most respondents mentioned that the identification or selection of desired and appropriate communication outcomes is very important in designing and evaluating the effectiveness of a communication KSA development program. However, the current systems predominantly focus on the superficial criteria for such evaluation or assess only the immediate outcomes such as improvement in the fluency of speech and so forth. The respondents emphasized on finding ways to improve the total communication package by evaluating the whole system and process of communication and not only the contents of it. Most respondents also believed that the current evaluation process overlooks or fails to capture the ultimate impact of apparently improved communication skills among the business executives mainly because the improvement in organizational outcomes are rarely measured in relation to the improvement of the contents (skills) and process (system and environment) of communication. There is currently no tool in place to measure the improvement of communication culture or environment or attitude according to the respondents. 


\section{Discussions and Conclusion}

Our findings largely corroborated with the extant and seminal business communication literature in emphasising on both the soft and hard skills of communication and its importance on the performance of business executives. Our respondents also acknowledged the important but deficient role of tertiary education system and curriculum in Bangladesh in developing the soft and hard communication skills. The English language (see Revell, 2007) and IT skills (see Groysberg \& Slind, 2012, Drussell 2012; Walther \& Valkenburg, 2017) have been identified as the most important hard communication skills in business organisations in Bangladesh. In line with the findings of Johnson and Bechler (1998), Luthra and Dahiya (2015) and Decker and Mitchel (2017) Whitener et al. (1998), our respondents also recognised trust, leadership, organisational culture and environment as important factors influencing the communication process. Our findings did not reveal any gendered issues influencing the process or outcome of communication. Our respondents were predominantly male which may have influenced the lack of insights into gender differences in the communication process and outcomes. A more extensive future research may explore this issue.

An important revelation from our findings is that most respondents viewed communication as a complex process and not just a set of skills with immediate individual performance outcomes. Effective communication is also generally viewed by our respondents as an organisational capability that must be sustained and nurtured in the culture to ensure greater and sustainable strategic outcomes as opposed to just an individual level skill, which is similar to Zerfass and Viertmann's, (2017) theory. Based on our 'a priori' and 'posteriori' themes, we proposed a total communication package for the business executives (see Figure 1) that can be used by the Bangladeshi business organizations and HR experts to develop sustainable and strategic communication capabilities within their respective organization. This TCP model may also be used by the future business communication researchers to design a more extensive qualitative or quantitative research to measure or compare the effectiveness of the communication process in different contexts.

\section{References}

Abbasi, M. H., Siddiqi, A., \& Azim, R. U. A. (2011). Role of Effective Communications for Enhancing Leadership and Entrepreneurial Skills in University Students. International Journal of Business and Social Science, 2(10), 242-250. Retrieved from http://ijbssnet.com/journals/Vol.\%202_No._10\%3B_June_2011/25.pdf

Aiken, M. W., Martin, J. S., \& Paolillo, J. G. P. (1994). Requisite Skills of Business School Graduates: Perceptions of Senior Corporate Executives. Journal of Education for Business, 69(3), 159-162. https://doi.org/10.1080/08832323.1994.10117676

Akhter, N., Khan, S. I., \& Hassan, M. K. (2009). Communication Skill of the Business Executives: An Empirical Study on Some Local Private Business Concerns in Bangladesh. International Business Research, 2(4). https://doi.org/10.5539/ibr.v2n4p109

Bambacas, M., \& Patrickson, M. (2008). Interpersonal communication skills that enhance organisational Commitment. Journal of Communication Management, 12(1), 51-72. https://doi.org/10.1108/13632540810854235

Bambacas, M., \& Patrickson, M. (2009). Assessment of communication skills in manager selection: some evidence from Australia. Journal of Management Development, 28(2), 109-120. https://doi.org/10.1108/02621710910932070

Bennett, J. C., \& Olney, R. J. (1986). Executive Priorities for Effective Communication in an Information Society. International Journal of Business Communication, 23(2), 13-22. https://doi.org/10.1177/002194368602300202

Berger, C. R. (1997). LEA's communication series. Planning Strategic Interaction: Attaining Goals Through Communicative Action (Routledge Communication Series) (1st ed.) . Mahwah, NJ, US: Lawrence Erlbaum Associates Publishers.

Cameron, C., Collie, C. L., Baldwin, C. D., Bartholomew, L. K., Palmer, J. L., Greer, M., \& Chang, S (2013). The development of scientific communication skills: a qualitative study of the perceptions of trainees and their mentors. Academic medicine: journal of the Association of American Medical Colleges, 88(10), 314-317. https://doi.org/10.1097/ACM.0b013e3182a34f36

Choren, A. (2015). The Importance of Communication in the Workplace. IEEE Potentials, 34(3), 10-11. https://doi.org/10.1109/MPOT.2014.2331793 
Clutterbuck, D., \& Hirst, S. (2002). Leadership Communication: A Status Report. Journal of Communication Management, 6(4), 351-354. https://doi.org/10.1108/13632540210807170

Cohn, K. H. (2007). Developing Effective Communication Skills. Journal of Oncology Practice, 3(6), 314-317. https://doi.org/10.1200/JOP.0766501

Cullen, C. B., \& Gordon, P. A. (2014). The Relationship between Leadership and Communication Skills of Nurse Managers and the Organizational Citizenship Behaviors of Medical - Surgical Nurses and Nursing Assistants. Management and Organizational Studies, 1(2), 23-29. https://doi.org/10.5430/mos.v1n2p23

Dasgupta, S. A., Suar, D., \& Singh, S. (2013). Impact of managerial communication styles on employees' attitudes and behaviours. Employee Relations, 35(2), 173-199. https://doi.org/10.1108/01425451311287862

Datar. S. M., Garvin, D. A., \& Cullen, P. G. (2011). Rethinking the MBA: Business Education at a Crossroads. Journal of Management Development, 30(5), 451-462. https://doi.org/10.1108/02621711111132966

Decker, P., \& Mitchel, J. (2017). Importance of Communication Skills for Leadership and Management. Manage Magazine. Retrieved from https://managemagazine.com/article-bank/self-handicapping-leadership/importance-communication-skills-1 eadership-management/

Drussell, J. (2012). Social Networking and Interpersonal Communication and Conflict Resolution Skills among College Freshmen. Retrieved from Sophia, the St. Catherine University repository. website: https://sophia.stkate.edu/msw_papers/21

Firth, L., Mellor, D. J., Moore, K. A., \& Loquet, C. (2004). How can managers reduce employee intention to quit? Journal of Managerial Psychology, 19(2), 170-187. https://doi.org/10.1108/02683940410526127

Gerstein, M., \& Reisman, H. (1983). Strategic Selection: Matching Executives to Business Conditions. Sloan Management Review, 24(2), 33-49. Retrieved from

https://www.researchgate.net/publication/13039103_Strategic_Selection_Matching_Executives_to_Busines s_Conditions

Graen, G. B., \& Scandura, T. A. (1987). Toward a psychology of dyadic organizing. Research in Organizational Behavior, 9, 175-208. Retrieved from https://www.researchgate.net/publication/232576635_Toward_a_Psychology_of_Dyadic_Organizig

Groysberg, B., \& Slind, M. (2012). Leadership Is a Conversation. Harvard Business Review. Retrieved from https://hbr.org/2012/06/leadership-is-a-conversation

Hull, R. H. (2012). Honing Your Communication Skills Benefits Patients, Colleagues, and You. The Hearing Journal, 65(4), 41-45. https://doi.org/10.1097/01.HJ.0000413505.24307.70

Iksan, Z. H., Zakaria, E., Meeran, S., Osman, K., Koh, D., Mahmud, S. N. D., \& Krish, P. (2012). Communication Skills among University Students. Procedia - Social and Behavioral Sciences, 59, 71-76. https://doi.org/10.1016/j.sbspro.2012.09.247

Johnson, S. D., \& Bechler, C. (1998). Examining the Relationship Between Listening Effectiveness and Leadership Emergence: Perceptions, Behaviors, and Recall. Small Group Research, 29(4), 452-471. Retrieved from https://journals.sagepub.com/doi/10.1177/1046496498294003

Kang, M., \& Sung, M. (2017). How symmetrical employee communication leads to employee engagement and positive employee communication behaviors: The mediation of employee-organization relationships. Journal of Communication Management, 21 (1), 82-102. https://doi.org/10.1108/JCOM-04-2016-0026

Katz, R. L. (1974). Skills of an Effective Administrator. Harvard Business Review. Retrieved from https://hbr.org/1974/09/skills-of-an-effective-administrator

Kombarakaran, F. A., Yang, J. A., Baker, M. N., \& Fernandes, P. B. (2008). Executive Coaching: it works. Consulting Psychology Journal Practice and Research, 60(1), 78-90. https://doi.org/10.1037/1065-9293.60.1.78

Luthra, A., \& Dahiya, D. R. (2015). Effective Leadership is all About Communicating Effectively: Connecting Leadership and Communication. International Journal of Management and Business Studies, 5(3), 43-48. Retrieved from http://www.ijmbs.com/Vol5/3/7-Anchal-Luthra.pdf

MacDonald, D. (1976). Communication Roles and Communication Networks in a Formal Organization. Human Communication Research, 2(4), 365-375. Retrieved from 
https://doi.org/10.1111/j.1468-2958.1976.tb00497.x

Majid, N. A., Jelas, Z. M., Azman, N., \& Rahman, S. (2010). Communication skills and work motivation amongst expert teachers. Procedia - Social and Behavioral Sciences, 7, 565-567. https://doi.org/10.1016/j.sbspro.2010.10.075

Markel, N. N., Long, J. F., \& Saine, T. J. (1976). Sex Effects in Conversational Interaction: Another Look at Male Dominance. Human Communication Research, 2(4), 356-364. https://doi.org/10.1111/j.1468-2958.1976.tb00496.x

Paksoy, M., Soyer, F., \& Çalik, F. (2017) .The impact of managerial communication skills on the levels of job satisfaction and job commitment. Journal of Human Sciences, 14(1), 642-652. https://doi.org/10.14687/jhs.v14i1.4259

Penley, L. E., Alexander, E. R., Jernigan, I. E., \& Henwood, C. I. (1991). Communication Abilities of Managers: The Relationship to Performance. Journal of Management, 17(1), 57-76. https://doi.org/10.1177/014920639101700105

Revell, P. R. (2007). Using English for International Business: A European case study. English for Specific Purposes, 26(1), 103-120. https://doi.org/10.1016/j.esp.2005.12.004

Robels, M. M. (2012). Executive Perceptions of the Top 10 Soft Skills Needed in Today's Workplace. Business Communication Quarterly, 75(4), 453-465. https://doi.org/10.1177/1080569912460400

Salvo, V. S. D. (1980). A summary of current research identifying communication skills in various organizational contexts. Communication Education, 29(3), 283-290. https://doi.org/10.1080/03634528009378426

Sistrunk, F., \& McDavid, J. W. (1971). Sex variable in conforming behavior. Journal of Personality and Social Psychology, 17(2), 200-207. https://doi.org/10.1037/h0030382

Smith, A. R. (2017). Communication Strategies Used During Organizational Change in a Health Care Organizations. Walden University. Retrieved from https://pdfs.semanticscholar.org/cc77/bacc05b6b5d6afc77edf1351ef837b65b50b.pdf

Walther, J. B., \& Valkenburg, P. M. (2017). Merging Mass and Interpersonal Communication via Interactive Communication Technology: A Symposium. Human Communication Research, 43(4), 415-423. https://doi.org/10.1111/hcre.12120

Whitener, E. M., Brodt, S. E., Korsgaard, M. A., \& Werner, J. M. (1998). Managers as Initiators of Trust: An Exchange Relationship Framework for Understanding Managerial Trustworthy Behavior. The Academy of Management Review, 23(3), 513-530. https://doi.org/10.5465/amr.1998.926624

Zerfass, A., \& Viertmann, C. (2017). Creating business value through corporate communication: A theory-based framework and its practical application. Journal of Communication Management, $21(1), 68-81$. https://doi.org/10.1108/JCOM-07-2016-0059

\section{Copyrights}

Copyright for this article is retained by the author(s), with first publication rights granted to the journal.

This is an open-access article distributed under the terms and conditions of the Creative Commons Attribution license (http://creativecommons.org/licenses/by/4.0/). 